\title{
Improvisation of Real-life Scenarios through Intercultural Competence
}

\author{
Celile Eren Okten ${ }^{1}$, Banu Ozer Griffin ${ }^{2}$ \\ ${ }^{1}$ Faculty of Education, Department of Teaching Turkish, Yildiz Technical University, Istanbul, Turkey \\ ${ }^{2}$ Department of Foreign Languages, Yildiz Technical University, Istanbul, Turkey \\ Correspondence: Banu Ozer Griffin, Faculty of Education, Department of Teaching Turkish, Yildiz Technical \\ University, Istanbul, Turkey.
}

\author{
Received: March 26, 2016 Accepted: April 12, $2016 \quad$ Online Published: May 10, 2016 \\ doi:10.11114/jets.v4i7.1496 URL: http://dx.doi.org/10.11114/jets.v4i7.1496
}

\begin{abstract}
This paper describes tasks based on real-life scenarios, which triggered reflective thinking, verbalization, and writing, leading to the creation of natural dialogues rather than artificial, dull monologues. One of the main aims of this approach is to engage students in a dynamic process of both learning about multicultural participants and presenting themselves. Data were collected from 30 students at a state university's Turkish and Foreign Languages Centre. Writing tasks were compiled through a classroom activity called "From Culture to Culture" (Kulturden Kulture), which invited students to conduct speaking and writing tasks while connecting their cultures with Turkish culture, utilizing intercultural competence's three components: knowledge, attitude and skill. Byram's (1997) multidimensional model of intercultural competence provided the theoretical framework for evaluation of intercultural competence expressed in students' reflective writing samples and oral presentations. Action research was conducted to promote more effective communicative styles in a multicultural classroom. Performance data were analyzed inductively, as each activity was adapted into a real-life scenario to study intercultural competence. Consequently, the real-life scenarios were categorized as knowledge, attitude and skill components in order to develop the flexibility and adaptability of the language learning process.
\end{abstract}

Keywords: intercultural competence, real-life scenarios, Turkish as a foreign language

\section{Introduction}

The purpose of the study is to encourage students to implement the flexibility and adaptability of the language learning process through intercultural competence with the contribution of real-life scenarios. Intercultural competence is "the ability to ensure a shared understanding by people of different social identities, and their ability to interact with people as complex human beings with multiple identities and their own individuality" (Byram, Gribkova, \& Starkey, 2002:5). Here, Byram (1997) identifies three major components of intercultural competence: knowledge, attitudes, and skills. Knowledge helps one to process one's own ideas and feelings about other social groups and their linguistic production. Attitudes comprise exhibiting curiosity and openness and a readiness to investigate other cultural practices. The skills to interpret and relate provide an ability to interpret symbols, events, documents, etc., while skills of discovery and interaction provide an ability to acquire new knowledge of cultural practices.

These three sets of intercultural competence do not follow a linear development as knowledge, skills, and attitudes may develop in different ways for different students. However, tasks can be devised to introduce knowledge of social processes and people's perception of a student's culture. Likewise, intercultural skills will be more likely to improve when students experience intercultural communication. Finally, attitudes may start to change over the process of the exchange. Here we conduct implementation of an intercultural exchange through writing and speaking tasks.

Here, the scenarios, or in other words, "hypothetical situations" (Beaven and Neuhoff, 2012:15) are especially created to improve students' oral and written skills. Moreover, they have "multiple dimensions like task type, language used, [and] scales used to assess the results..." in order to activate both language production and intercultural competence (Walinski, 2012). Designing activities based on everyday experiences aim to lower anxiety caused by multilingual and multicultural differences. Nevertheless, studying in a multicultural classroom might have some challenges for classroom interaction. Therefore, it would be useful to construct dimensions of intercultural competence with regard to real-life scenarios. Knowledge and skill could exist in traditional activity settings because they are easily evaluated through 
grammatical patterns and linguistic production (Fantini, 2000). But, as a third component and the final stage of intercultural competence, attitude is closely related to learning outcome and determines the effect, positive or negative, on acquisition.

Byram's multidimensional model of intercultural competence (1997) posits the competencies in knowledge, skill and attitude for effective communication in a foreign language. While discovering the similarities and differences between cultures, learners are exposed to interpreting everyday experiences, and asked to relate them to the target language and its culture.

Commonly shared real-life scenarios allow students to exchange their beliefs, worldviews, and cultural practices, which in turn leads them to become engaged in "a dynamic process of inquiry, discovery, exploration, and interpretation" (Furstenbeg, 2010a cited in Moeller \& Nugent, 2014). Both teacher and student are able to track the learning process and focus on critical reflection, self-evaluation and two-sided feedback (Shute, 2007).

Is it necessary to observe how students develop knowledge, attitude and skill in an intercultural exchange? Reflective and critical practices through scenarios in the classroom are essential to promote intercultural learning and linguistic knowledge (Kern, 2000; Kramsch \& Thorne, 2002; O’Dowd, 2003; Guth \& Marini-Maio, 2010). This is as true for the language-teaching professional's process of facilitation as it is for the learner's processes of language acquisition and intercultural competence.

\section{Method}

\subsection{Research Design}

This study is qualitative, for "the overall purposes of qualitative research are to achieve an understanding of how people make sense out of their lives, delineate the process (rather than the outcome or product) of meaning-making, and describe how people interpret what they experience" (Merriam, 2009:14). Merriam (2009) identifies four key characteristics of qualitative studies: the centrality of the participants' perspective on the research interest, the role of the researcher as the main instrument for data collection and analysis, the inductive process of the study, and finally, the rich description of participants' interviews, and the researcher's field notes and observations. The characteristics of the qualitative study are particularly well suited for this research as the focus is the participants' perspectives on their experience in the intercultural exchange. In addition, the study used multiple sources of data, such as observations, students' essays and classroom oral presentations to understand their perceptions about intercultural experiences.

Action research (Patton, 2002; Johnson, 2002; Creswell, 2012; Mertler, 2012) was conducted in order to explore more effective communicative learning strategies in a multicultural classroom through tasks involving real-life scenarios. Shetzer and Warschauer (2000) suggest that in action research, teachers and students work collaboratively "to reflect critically on the issues they discovered during their research and to revise future teaching, learning, or research plans" (p. 183). While this study seeks to understand the experience of learners in developing intercultural competence through reflective and experiential tasks, the goal of the study is also to understand how knowledge, attitudes and skills function through scenarios in the language learning process (Stringer, 2007).

\subsection{Participants and Setting}

The ages of the students in the group ranged from 18-30, all of whom took one year of preparatory Turkish in 2014-2015 before starting their university education in the academic year 2015-2016. Within the group of 25 students, some were undergraduates and some were graduate students. Students came from a variety of countries. Most of them were from the Middle East, some were from Africa and East Asia, and the rest were from Eastern Europe.

Students began to learn Turkish in the beginning of the fall semester (October) and continued to do so until the end of the spring semester (June), a total of 8 months. They completed the A1 level, A2 level and B1 level from October, 2014 to March, 2015, which was the timeframe taken for the data set, as A1, A2, and B1 are the minimum requisite levels for entering into a Turkish-based academic career.

During this preparatory period, students had 5 hours of class every day, five days a week. There were also many other opportunities for learning. They stayed in dormitories; they had Turkish roommates with whom they could communicate, and they lived in Turkey (which meant they had to deal with everyday life issues like commuting, shopping, watching Turkish movies/TV series), and they ran formal or institutional errands such as obtaining residence permits or registering for their departments.

Classes took place on the university campus. The classrooms had 25-30 seats and had no means of technological support like projectors or internet connection. Teaching was based on the coursebook and extra materials handed out by the teachers if needed. 


\subsection{Data Collection}

The theoretical framework for this study was based on the multidimensional model of Byram's intercultural competence (1997). There is an emphasis on the connections between improvisation of real-life scenarios and flexible/communicative learning processes. The main components of intercultural competence-knowledge, attitudes and skills - foster these connections in order to concentrate on both students' intercultural competencies and linguistic knowledge.

The purpose of this study is:

1. To plan, implement, and evaluate intercultural competence for language learning processes.

2. To develop communicative learning strategies for linguistic knowledge through real-life scenarios.

Data were collected through writing tasks, "From Culture to Culture", which were at the end of each unit in the coursebook, and through speaking tasks about the topic and real-life experiences. Tasks were presented as real-life scenarios, so the students could adapt them into their own cultural format and then find pertinent examples. Briefly, data sources included the coursebook, reflective paragraphs, and classroom discussions about culture-salient issues.

\subsection{Data Analysis}

The researchers adopted the tactics developed by Miles and Huberman (1994) to generate meaning from the content of data. These noting patterns and themes, clustering cases, making contrasts and comparisons, partitioning variables, all for testing or confirming the findings therein (pp. 245-262). Tactics mentioned here help to build systematic "safeguards against self-delusion" (p. 265) into the process of analysis.

Therefore, over a six-month period, we observed how learners adapted cultural themes found in the coursebook into scenarios through the descriptions of their local experiences. Due to the multicultural sharing atmosphere of the classroom, they often introduced and compared their own cultural practices and expressions. Consequently, scenarios were created in order to facilitate the transitions between students' own cultures and Turkish culture.

First, the students read the texts found in the section, "From Culture to Culture" and then they were expected to comprehend the topic through familiar cultural features. They were allowed to create their own scenarios, which were extracted from their own cultural backgrounds. Based on these scenarios, writing and speaking tasks were designed in order to introduce their own perceptions of Turkish language and culture. For instance, they discussed rituals within the scenarios of celebrations and tried to interpret them using the language they heard on the street, in school or in dormitories. They were then asked to write their own paragraphs and give examples from their own countries by using the text they read as a model and to try to adapt the vocabulary and linguistic usages found in the same text.

Finally, we scanned all the writing samples, which were generated from the topics presented in the "From Culture to Culture" sections. After an impressionistic review of cultural expressions, we inductively developed a coding scheme that reflected the effectiveness of intercultural competence on writing and verbalization. All codes on the writings were color-marked and re-examined by both researchers. Subsequently, the list was revised by both the researchers and the students. Two researchers independently compared interpretive analyses, which were based on the highlighted main themes. These member checkings provided the reliability and validity of the study. After coding, listing and checking the reliability, the researchers developed a series of flow charts independently that map out knowledge, attitudes and skills for each topic. These charts helped to support intercultural evidence that emerged from the established data. Eventually, the concept of intercultural competence was combined with their linguistic knowledge of Turkish. This was also improved by adjusting attitudes towards other cultures, and finally, by implementing skills to relate and interpret with the help of contextual grammar within this framework.

\section{Findings}

Developing students' knowledge, attitudes and skills in intercultural competence motivated them to use the target language. Thus, creating scenarios with modelling writing and daily speech with cultural experiential examples helped them to develop both intercultural competence and linguistic knowledge. It is widely accepted that coursebooks are basic tools for teaching intercultural competence in the classrooms. They have the main components of intercultural competence, which are knowledge, attitude, interpreting and relating skills. These components help to assess intercultural competence. Moreover, coursebooks draw students' attention to the similarities and differences between their first language and the target language, and these classroom activities motivate them to imply authenticity or real life scenarios that can be improvised through writing and speaking tasks. For instance, approaches to making coffee can vary from culture to culture, and giving instructions for how to do it may be a good writing or speaking task. Such types of creative tasks enable students to enjoy multi-modality in education in the sense of culture and foreign language learning (Bandura, 2008). 
In this study, the coursebooks Istanbul $A 1, A 2$ and $B 1$ provide a good communicative method of teaching Turkish language and culture to TOMER students. In the section entitled "From Culture to Culture", students are culturally exposed to specific concepts of food, celebration, marriage engagement, respect, etc., which allow students to become aware of linguistic competence, sociolinguistic competence and pragmatic competence. Moreover, during these speaking and writing tasks, they become socialised and motivated to produce and interpret spoken and written language.

There are six units in Istanbul Al. The topics of the first three units are Identifying Places, Shops and Students. In the first unit, students identified sites like the Ortakoy Mosque in Istanbul, the Pisa Tower in Italy, and the Statue of Liberty in New York. They gave examples from their countries like the Aleppo Citadel in Syria or Socotra Island in Yemen. The second unit is about working hours and the days upon which shops are open in Turkey, Japan and Egypt. They talked about the similarities and differences between cultures, for example the fact that in Afghanistan no shops are open 24/7. In some instances, they shared the same vocabulary, for instance, 'Cuma' ('Friday'). The third unit is about students and the lives of three students who are studying at universities in Turkey, Germany and Ghana. They were asked to talk about their own cultural lives and their experiences in Turkey. For example, in Zimbabwe, the students live on campus, but in Yemen, however, there are no dorms.

The last three units are about Families, Interesting Festivals and Conversation Culture. Unit Four is about family types from Turkey, the US and Japan. Students described the family types in their culture. For instance, in Montenegro there are usually four people in families, while in Afghanistan they have 7-8 people in each family. They made comments about the situation and wrote a paragraph about family types. Unit 5 is about three festivals: the Hidirellez festival in Turkey, the Tomato festival in Spain, and the Holi Colour festival in India. Students were asked to describe and discuss festivals in their own cultures. They came up with examples such as the Shiri Badat Cannibal King Festival in Pakistan and Independence Day in Sierra Leone. Students listened to each other carefully and were then asked to write down information about their festivals. Unit 6 covers formal conversation in Turkish, Arabic and English cultures. Students shared vocabulary items that are written the same across multiple languages but have different meanings, for example 'sohbet' means 'chat' in Turkish and Persian but means 'like' in Arabic (see Table 1).

The Istanbul A2 book also has 6 units. The first three units are about Food Culture, People in the Sky, and the World of Coffee. 'Food Culture' is about food around the world. There are six people talking about their country's food: Chinese, Iranian, Italian, Russian, French and Egyptian. The students were asked to name six other types of food given in the pictures. They then talked about foods from their own countries, such as Mantu (a kind of dumpling) from Afghanistan. In the second unit they read about inventors: Hezarfen Ahmet Chelebi and The Wright Brothers. They talked and wrote about inventors from their countries. The third unit is about the World of Coffee in Turkey, Indonesia and Yemen. As they were talking, students shared information about ceremonies and tea cultures as well. For example, in Iraq they only serve tea after someone has passed away, and in Tunisia, tea is served with mint and sugar after meals.

The topics of the last three units are: Legends, Traditional Plays and Folk Dances. In Unit 4, students read about two legends, one from Turkey and the other from Korea. They were then asked to discuss a legend from their countries, such as the legend of the hero Amirani from Georgia. In Unit 5, students read about three traditional puppet shows: Karagoz and Hacivat from Turkey, Longdong from China, and Bunraku from Japan. They talked about similar legends in their countries. In Unit 6, they read about traditional dances: Zeybek from Turkey, Tango from Buenos Aires, and Northeast African Dancing. Then the students talked about traditional dances from their countries, including Chobi, from Iraq (see Table 2).

There are six units in Istanbul B1. The topics of the first three units are New Life, Business Life, and Health. In the first unit, students were prompted to talk about their new lives in Turkey. They shared stories of moving and of discovering Istanbul. For example, an Afghan student was shocked to see women smoke cigarettes. The second unit is about Business Life, wherein students learn about the success stories of certain business people and how to choose their jobs; Jahurul Islam, a Bangladeshi businessman, is given as an example. Students talked about the people they know and their careers in the future. In the third unit, they learn about health and leading a healthy life. They read about healthy diets, living long and alternative medicine. Students made comments and gave examples from their country's health culture. For example, in Iraq, ginger and milk are used to relieve stomach pain.

The last three units are about Education Life, Our Dreams and People Talking. Unit Four is about learning types and learning Turkish. Students talked about how they learn things, as well as what they were thinking and feeling while learning Turkish. They compared their own languages with Turkish; 'hemshire' means sister in Persian but nurse in Turkish. Unit 5 is about dreams starting by talking about the "I wishes" in students' lives, as well as the "what ifs" and how to get over them. Most students wished to be with their families again soon. Unit 6 is about how people talk, prompting communication on different issues. The students talked about sharing a flat, the structure of a Turkish family, and relations with neighbors. They gave examples from their cultures. For example, in Ethiopia it is not appropriate to 
ask someone personal questions, her/his age, for example (see Table 3).

After discussing how the coursebook was implemented, the section below will discuss classification according to the components of intercultural competence.

\subsection{Knowledge}

As most students in the class were from the Middle East, were of the same religion, and were adults, they immediately connected along certain cultural codes (lines of cultural identity). The Istanbul Al book relies on students' previous knowledge of famous sites around the world and in Turkey. By the end of each unit, they completed one of the following tasks: writing a brief informative paragraph about shops in their countries, discussing university students' lives and family types from their countries, describing interesting festivals held in their countries, and identifying an aspect of conversational culture in their societies. The Istanbul A2 book relies on students' previous knowledge of certain types of food around the world and in Turkey. By the end of each unit, they completed one of the following tasks: writing a recipe for a famous dish from their culture, discussing inventors from their country, discussing the coffee and tea cultures of different countries, reading about a legend from Turkey and relating a legend or a story from their countries, learning about shadow plays and describing similar activities for children in their cultures, and reading about folk dances in Turkey and talking about folk dances from their countries. The Istanbul Bl book relies on students' life and personal experiences. By the end of each unit, they completed one of the following tasks: sharing their stories of living in Istanbul, writing a short biography of a successful businessman from their countries, writing about their future career goals, discussing how to live a healthy life, discussing learning Turkish, writing about their regrets and wishes, and talking about cultural differences in communication.

\subsection{Attitudes}

Students were very motivated from the first day of classes. Using the Istanbul Al book, in the first unit they began identifying places and gave examples of their own, trying to find similar examples to the Turkish ones provided. In the second unit, they enjoyed finding out facts about shops in Turkish culture, and they started talking naturally about the opening and closing hours for shops in their countries. They were again willing to talk about conditions here and in their countries when the subject came up in the third unit. Then, in the fourth unit they were surprised about how crowded some of their fellow students' families were, and they joked about it because they felt comfortable with one another. They enjoyed reading about festivals and they all wanted to share information about their countries' festivals with everyone in the fifth unit, and everyone enjoyed listening to one another. In the sixth unit while students were talking about conversational mores from their cultures, they shared some common vocabulary and social rules from the languages and cultures of their home countries.

In the second level (using the Istanbul A2 book), students started with food culture and talked about the dishes they had tried in Turkey. They were also enthusiastic about talking about their cultures' traditional or famous dishes. In the second unit, they read about two inventors who were able to fly. They tried to find similar stories from their countries. In the end they proudly talked about inventors or scientists from their cultures. In discussing coffee during the third unit, they immediately connected the topic with their cultures. They talked about ceremonies and occasions where coffee or tea is served. In the fourth unit they told legends from their countries and talked about the moral lessons given through legends or criticism of traditions presented in legends. Next, in the fifth unit, they read about puppet plays and tried to understand how they work. They were curious about this, as no student had such an activity in his or her culture. Finally, in the sixth unit they talked about when and how their folk dances took place, and they were eager to learn from and share with others.

In the Istanbul Bl book, students began with the topic of moving to another country and talked about their first weeks in Turkey. In the second unit, they read about a successful Turkish businessperson and wrote about their countries' examples of the same. They also talked about how to be successful in business life and shared their opinions. In discussing health and life during the third unit, they were interested in health remedies from each other's countries and compared them. They talked about learning Turkish in the fourth unit and enthusiastically discussed how they study and what should change in the coursebook. Next, in the fifth unit, they wrote about their regrets and wishes, sharing stories and supporting each other. Finally, in the sixth unit they talked about cultural differences in communication. They had fun when talking about the differences between Turkish culture and their own.

\subsection{Skills}

In order to avoid any misunderstandings related to cultural situations or politeness, it is significant to develop skills in discovering, relating and interpreting the other (Byram, 1997). After the "From Culture to Culture" section, students have to use five basic skills: reading, grammar, vocabulary, speaking and writing. The texts in the "From Culture to Culture" sections have three paragraphs; one paragraph is always about Turkish culture, and the other two are from 
different cultures. This is the part where students use the five skills all together through the following steps. First, the texts are read out loud by the students. Second, they read it again in silence, followed by questions to the teacher; this is where the students practice reading skills.

Briefly, these tasks are creative as they encourage different uses of vocabulary and, sometimes, different structures when they write their own stories. Students are to ask the teacher how to say certain things and use their dictionaries to find new words. The level of willingness to talk about their own cultural features decreases when it is time for writing, as they have a harder time putting what they say into writing. They try to build correct sentences and make fewer mistakes, and as a result they spend energy focusing on accurate grammar moreso than they would in an improvised style, so as to trigger writing fluency.

The following table shows the classification of the components of intercultural competence according to the units and how the topics were integrated and synthesized with knowledge, attitude and skill:

Table 1. A1 Book

\begin{tabular}{|c|c|c|c|c|}
\hline A1 & TOPIC & KNOWLEDGE & ATTITUDE & SKILL \\
\hline $\begin{array}{c}\text { UNIT } \\
1\end{array}$ & $\begin{array}{lll}\text { WHERE } & \text { IS } & \text { THIS } \\
\text { PLACE } & & \end{array}$ & $\begin{array}{l}\text { Well-known historical and } \\
\text { natural sites in their countries: } \\
\text { Socotra island in Yemen, Aleppo } \\
\text { Citadel in Syria. }\end{array}$ & $\begin{array}{ll}\text { Introducing the best } \\
\text { examples in their } & \text { own } \\
\text { countries. Trying to find } \\
\text { similar sites in Turkey. }\end{array}$ & $\begin{array}{lr}\text { Grammar } & \text { oriented: } \\
\text { exemplifying, } & \text { identifying } \\
\text { places, basic interaction. }\end{array}$ \\
\hline $\begin{array}{l}\text { UNIT } \\
2\end{array}$ & SHOPS & $\begin{array}{l}\text { Working days and hours; } \\
\text { shopping times: Closed on } \\
\text { Fridays, no 24/7 shops in } \\
\text { Afghanistan. }\end{array}$ & $\begin{array}{l}\text { Introducing their countries' } \\
\text { work schedules. Enjoy } \\
\text { hearing about the shops open } \\
24 / 7 \text { in Istanbul. }\end{array}$ & $\begin{array}{l}\text { Willingly talk and share } \\
\text { together to teach each other } \\
\text { vocabulary; written time } \\
\text { scheduling. }\end{array}$ \\
\hline $\begin{array}{l}\text { UNIT } \\
3\end{array}$ & STUDENTS & $\begin{array}{l}\text { University students' } \\
\text { accommodation and daily lives: } \\
\text { In Zimbabwe Ss live in campus } \\
\text { dormitories, no dorms in Yemen. }\end{array}$ & $\begin{array}{l}\text { What universities provide } \\
\text { students, dorm conditions, } \\
\text { renting a flat with friends. } \\
\text { They are willing to compare } \\
\text { conditions in Turkey and in } \\
\text { their countries. }\end{array}$ & $\begin{array}{l}\text { Making definitions; listing } \\
\text { similarities and differences; } \\
\text { making connections. }\end{array}$ \\
\hline $\begin{array}{c}\text { UNIT } \\
4\end{array}$ & FAMILIES & $\begin{array}{l}\text { Family types in cities and } \\
\text { villages; cultural differences: In } \\
\text { Montenegro families are usually } \\
4 \text { people, in Afghanistan they are } \\
7-8 \text {. }\end{array}$ & $\begin{array}{l}\text { Being surprised upon hearing } \\
\text { about crowded families; } \\
\text { respecting all types. }\end{array}$ & $\begin{array}{l}\text { Describing their own cultures; } \\
\text { making comments orally and } \\
\text { modelling the written } \\
\text { structure. }\end{array}$ \\
\hline $\begin{array}{l}\text { UNIT } \\
5\end{array}$ & $\begin{array}{l}\text { INTERESTING } \\
\text { FESTIVALS }\end{array}$ & $\begin{array}{l}\text { Religious and National festivals; } \\
\text { e.g. Hidirellez, Ramadan, Holi } \\
\text { Colour (India), Tomato (Spain); } \\
\text { gathering places such as } \\
\text { hamams, tombs, mosques, etc. }\end{array}$ & $\begin{array}{l}\text { Introducing an important } \\
\text { festival with its cultural and } \\
\text { religious practices. }\end{array}$ & $\begin{array}{l}\text { Listening to each other very } \\
\text { carefully and having a } \\
\text { discussion about festivals; } \\
\text { writing an introductory } \\
\text { paragraph about their festivals. }\end{array}$ \\
\hline $\begin{array}{l}\text { UNIT } \\
6\end{array}$ & $\begin{array}{l}\text { CONVERSATION } \\
\text { CULTURE }\end{array}$ & $\begin{array}{l}\text { Hierarchy of conversation with } \\
\text { regard to age, social status, } \\
\text { gender, etc. } \\
\text { Topics: Politics, religion, job, } \\
\text { health, family, sports. }\end{array}$ & $\begin{array}{l}\text { How borrowed words travel } \\
\text { around cultures and } \\
\text { socio-moral regulations in } \\
\text { using them. }\end{array}$ & $\begin{array}{l}\text { Sharing and using vocabulary, } \\
\text { turn-taking, opening gambits, } \\
\text { politeness, generating } \\
\text { problem-solving expressions. }\end{array}$ \\
\hline
\end{tabular}


Table 2. A2 Book

\begin{tabular}{|c|c|c|c|c|}
\hline A2 & TOPIC & KNOWLEDGE & ATTITUDE & SKILL \\
\hline $\begin{array}{c}\mathrm{UNIT} \\
1\end{array}$ & $\begin{array}{l}\text { FOOD } \\
\text { CULTURE }\end{array}$ & $\begin{array}{l}\text { Ingredients, recipes, serving dishes } \\
\text { for meals, styles of diets and treats. } \\
\text { E.g. Mantu (Afg), Dolma (Syria), } \\
\text { Priganice (during Ramadan in } \\
\text { Montenegro). }\end{array}$ & $\begin{array}{l}\text { Table manners, } \\
\text { appreciating, politeness. }\end{array}$ & $\begin{array}{l}\text { To be able to talk about picture } \\
\text { presentations of food: } \\
\text { read-watch-talk-writing a recipe. }\end{array}$ \\
\hline $\begin{array}{l}\text { UNIT } \\
2\end{array}$ & $\begin{array}{l}\text { PEOPLE IN THE } \\
\text { SKY }\end{array}$ & $\begin{array}{l}\text { Inventors, artists, scientists from } \\
\text { their own countries. E.g. Hezarfen } \\
\text { Ahmet Chelebi, Dr. Kaled Nashwah } \\
\text { (Afg), Muhammed Gani Hikmet } \\
\text { (Iraq). }\end{array}$ & Praising the East. & $\begin{array}{l}\text { Making connections and } \\
\text { comparisons; writing an opinion } \\
\text { paragraph. }\end{array}$ \\
\hline $\begin{array}{c}\text { UNIT } \\
3\end{array}$ & $\begin{array}{l}\text { WORLD } \\
\text { COFFEE }\end{array}$ & $\begin{array}{l}\text { Coffee and tea cultures of home } \\
\text { countries. E.g. Tea with mint; green } \\
\text { tea with almond; Luwak coffee } \\
\text { (Indonesia). }\end{array}$ & 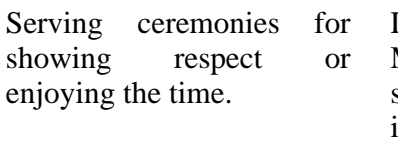 & $\begin{array}{l}\text { Discussion on the topic; } \\
\text { Matching and identifying } \\
\text { sentences, making guesses and } \\
\text { inferences. }\end{array}$ \\
\hline $\begin{array}{c}\text { UNIT } \\
4\end{array}$ & LEGENDS & $\begin{array}{l}\text { Local folk tales; moral lecturing. } \\
\text { E.g. Bride Rock, Amirani (Georgia) }\end{array}$ & Criticizing traditions. & $\begin{array}{l}\text { Reading comprehension; telling } \\
\text { a story. }\end{array}$ \\
\hline $\begin{array}{l}\text { UNIT } \\
5\end{array}$ & $\begin{array}{l}\text { TRADITIONAL } \\
\text { PLAYS }\end{array}$ & $\begin{array}{l}\text { Shadow play: Karagöz-Hacivat; } \\
\text { children's games. E.g. Hijla } \\
\text { (Sudan), Houses (Afg), Red mask } \\
\text { (Zimbabwe). }\end{array}$ & $\begin{array}{l}\text { Being curious about the } \\
\text { shadow play since they } \\
\text { have almost no idea about } \\
\text { this topic; only Bangledesh } \\
\text { has puppet plays. }\end{array}$ & $\begin{array}{l}\text { Listening and comprehending } \\
\text { the event or rule; note-taking } \\
\text { about these events or rules. }\end{array}$ \\
\hline $\begin{array}{l}\text { UNIT } \\
6\end{array}$ & FOLK DANCES & $\begin{array}{l}\text { Folk songs, costumes, dance } \\
\text { figures, musical instruments, such } \\
\text { as Zeybek, Tango, and African } \\
\text { dances. E.g. Chobi (Iraq), Dhant } \\
\text { (Somali), Shak (Yemen). }\end{array}$ & $\begin{array}{l}\text { How and when they are } \\
\text { performed. }\end{array}$ & $\begin{array}{l}\text { Dealing with audiovisiual } \\
\text { materials; Giving information, } \\
\text { interpreting cultural symbols. }\end{array}$ \\
\hline \multicolumn{5}{|c|}{ Table 3. B1 Book } \\
\hline B1 & OPIC & NOWLEDGE & ATTITUDE & SKILL \\
\hline $\begin{array}{c}\text { UNIT } \\
1\end{array}$ & A NEW LIFE & $\begin{array}{l}\text { How to rent a flat, how Ss feel and what } \\
\text { they are experiencing in their new lives. } \\
\text { In Syria there are flats near campuses for } \\
\text { reasonable prices. }\end{array}$ & $\begin{array}{l}\text { Introducing their personal } \\
\text { experiences. Women } \\
\text { smoking was shocking for } \\
\text { Afghan students. }\end{array}$ & $\begin{array}{l}\text { Speaking oriented: talking } \\
\text { about experiences, daily } \\
\text { conversation skills. }\end{array}$ \\
\hline $\begin{array}{c}\text { UNIT } \\
2\end{array}$ & $\begin{array}{l}\text { BUSINNESS } \\
\text { LIFE }\end{array}$ & $\begin{array}{l}\text { Successful business people; how to } \\
\text { choose a job? E.g. Jahurul Islam, a } \\
\text { Bangladeshi businessman, very } \\
\text { successful at marketing, construction and } \\
\text { real estate. }\end{array}$ & $\begin{array}{l}\text { Introducing the best } \\
\text { examples from their own } \\
\text { countries, and talking about } \\
\text { their future careers. }\end{array}$ & $\begin{array}{l}\text { Grammar and vocabulary } \\
\text { oriented. Participals and } \\
\text { vocabulary: } \quad \text { Business } \\
\text { related. }\end{array}$ \\
\hline $\begin{array}{c}\text { UNIT } \\
3\end{array}$ & HEALTH & $\begin{array}{l}\text { About health and healthy living/giving } \\
\text { advice: Using Chamomile for flu, and } \\
\text { ginger and milk for abdominal pain in } \\
\text { Iraq. }\end{array}$ & $\begin{array}{l}\text { Commenting on the texts } \\
\text { and stating their opinions } \\
\text { on how to live a heathy life. }\end{array}$ & $\begin{array}{l}\text { Necessity } \\
\text { patterns; } \\
\text { vocabulary. }\end{array}$ \\
\hline $\begin{array}{l}\text { UNIT } \\
4\end{array}$ & $\begin{array}{l}\text { EDUCATION } \\
\text { LIFE }\end{array}$ & $\begin{array}{l}\text { Types of learning, learning a foreign } \\
\text { language: How Urdu and Turkish are } \\
\text { similar in terms of vocabulary borrowed } \\
\text { from Persian and Arabic. }\end{array}$ & $\begin{array}{l}\text { Talking about their skills, } \\
\text { their education, and } \\
\text { experiences in learning } \\
\text { Turkish. }\end{array}$ & $\begin{array}{l}\text { Gerunds; education-related } \\
\text { vocabulary. }\end{array}$ \\
\hline $\begin{array}{l}\text { UNIT } \\
5\end{array}$ & $\begin{array}{l}\text { OUR } \\
\text { DREAMS }\end{array}$ & $\begin{array}{l}\text { About regrets wishes and "what ifs" in } \\
\text { life. Personal examples from their lives; } \\
\text { an Afghan girl wished she was with her } \\
\text { mother. }\end{array}$ & $\begin{array}{l}\text { Talking about their dreams } \\
\text { and wishes, stating } \\
\text { opinions. }\end{array}$ & $\begin{array}{l}\text { Sharing and using } \\
\text { vocabulary related to } \\
\text { dreams, wishes, regrets and } \\
\text { superstitions. }\end{array}$ \\
\hline $\begin{array}{l}\text { UNIT } \\
6\end{array}$ & $\begin{array}{l}\text { PEOPLE } \\
\text { TALKING }\end{array}$ & $\begin{array}{l}\text { Reading and listening to texts about } \\
\text { relations between flatmates, family } \\
\text { members, and neighbors. E.g.Personal } \\
\text { questions are not asked in Ethiopia. }\end{array}$ & $\begin{array}{l}\text { Introducing examples of } \\
\text { relationships from their } \\
\text { own countries. }\end{array}$ & $\begin{array}{l}\text { Describing the environment } \\
\text { they are in, sharing } \\
\text { information. }\end{array}$ \\
\hline
\end{tabular}

\section{Results}

We observed that while the students were giving examples from their countries and explaining them, they made connections between knowledge of their own cultures and that of the target language, which is Istanbul Turkish in this case. Not only did they demonstrate the similarities between examples from their cultures, but they also transferred their knowledge to the other learners of the target language, thereby building an intercultural competence. By doing so, they understood the process of how they were learning the target language and this, in turn, opened up the possibility of an increase in the speed and quality of language learning. 
In the first unit of the first book (A1), all of the students were shy, a common experience new learners face in general. However, as they started talking about well-known sites around the world like the Pisa Tower in Italy and started giving examples of famous sites in their countries like the Aleppo Citadel in Syria, their reticence began to fade and they became more active. This positive and motivated behavior also led to them laying the groundwork for strong relations with their classmates as well. By the end of second unit they were willing to talk; moreover, they started to write about their countries' work schedules, such as how, in Afghanistan, all the shops are closed on Fridays, whereas they are not in Turkey. This type of cultural knowledge made them adjust their lifestyle to that of Turkish society and began to show them how they would have to be mentally and culturally flexible to learn Turkish and live in Istanbul. In the third unit, they were able to define and compare their experience as students between the target culture and their cultures. For example, the life of a university student is easier in Zimbabwe than in Yemen, and it is moderately easy in Turkey. As they started sharing and writing more about their own cultures and the target culture, the class participants became better friends with each other; they shared stories from their daily lives in Turkey and talked about interesting things that happened to them, all the while using Turkish language and Turkish gestures. By the end of the third unit, the students were so eager to talk about their cultures and ask questions about the target culture and other cultures that the teacher had to work hard to make sure everyone spoke in turn.

\section{Discussion}

After everyone participated in classroom discussions and listened to others talking about their cultural experiences, the teacher gave students written assignments. For example, in the A2 book they wrote about "legends" from their countries. They read about some legends from Turkey and learned more about the subject by asking questions about it. This allowed them to put everything onto paper in an organized way, leading the learners to understand the meta-conditions of their learning process. With the completion of the third book, B1, the learners acquired many skills that made them feel comfortable with the target language and its culture. As they read and talked about Turkish culture, they learned about what to expect and what to do or say in certain situations. For instance, in Ethiopia no personal questions are asked when you meet someone for the first time, such as their age or salary, whereas asking personal questions is not considered rude in Turkish culture. As their cultural awareness levels were considerably increased, they were able to talk using a wide range of vocabulary; for example, they were able to express their wishes and dreams, write using correct grammatical structures (such as making comparisons between their first languages and Turkish), and they became aware of the cultural features of the Turkish language as well as being able to differentiate between what is polite and what is impolite.

Thus, returning to Byram's (1997) description of intercultural competence—students' attitudes towards the other culture in the exchange, students' knowledge of social processes and the way other cultures perceive them, and students' skills developed in intercultural exchange such as communication strategies - the real-life intercultural competence scenarios utilized in the current study motivated students to take part in the cultural situations unfolding around them. This instilled in them the flexibility and adaptability to manage these new unfamiliar situations and to absorb new knowledge. Since the learning process is actually related to the cognitive, affective and behavioral dimensions of intercultural competence (Williams, 2009), the improvisation of real-life scenarios which could present various tasks helped enable students to reach and complete the threshold level (B1) of Turkish relatively quickly and directly, and to achieve a corresponding level of intercultural competence.

\section{References}

Bandura, E. (2008). Intercultural Dialogue in Reading Foreign Language Literature. In Mańczak-Wohlfeld E. (ed.), Studia Linguistica Universitatis Iagiellonicae Cracoviensis, 125, 19-27. Krakow: Wydawnictwo Uniwersytetu Jagiellońskiego.

Beaven, A., \& Neuhoff, A. (2012). Assessing Oral Proficiency for Intercultural Professional Communication: The CEFcult Project. European Association for Computer-Assisted Language Learning (EUROCALL), 13-16. Retrieved on November 6, 2015 http://files.eric.ed.gov/fulltext/ED544436.pdf.

Byram, M. (1997). Teaching and assessing intercultural communicative competence. Clevedon: Multilingual Matters.

Byram, M., Gribkova, B., \& Starkey, H. (2002). Developing the intercultural dimension in language teaching. A practical introduction for teachers. Strasbourg: Council of Europe. Retrieved on October 8, 2015 http://lrc.cornell.edu/rs/roms/507sp/ExtraReadings/Section0/Section0/uploads/File1235272745204/InterculturalDi mensionByram.pdf.

Creswell, J. W. (2012). Educational research: Planning, conducting, and evaluating quantitative and qualitative approaches to research (4nd ed.). Boston, MA: Pearson.

Fantini, A. E. (2000). A central concern: Developing intercultural competence. In A. Fantini (ed.), SIT Occasional Papers Series Addressing Intercultural Education, Training \& Service, About our institution, 25-42. School for 
International Training, Brattleboro, Vermont. Retrieved on October 7, 2015 http://citeseerx.ist.psu.edu/viewdoc/download?doi=10.1.1.117.8512\&rep=rep1\&type=pdf\#page=33.

Furstenberg, G. (2010). A dynamic, web-based methodology for developing intercultural understanding. Proceedings of the 3rd international conference on intercultural collaboration, 49-58. http://dx.doi.org/10.1145/1841853.1841861

Guth, S., \& Marini-Maio, N. (2010). Cose Encounters of a New Kind: The Use of Skype and Wiki in Telecollaboration. In S. Guth and F. Helm (eds.), Telecollaboration 2.0: Language, Literacy and Intercultural Learning in the 21st Century (pp. 413-426). Bern: Peter Lang.

Johnson, A. P. (2002). A short guide to action research. Needham Heights, MA: Allyn and Bacon.

Kern, R. G. (2000). Literacy and Language Teaching. Oxford: Oxford U. Press.

Kramsch, C., \& Thorne, S. (2002). Foreign Language Learning as Global Communicative Practice. In D. Block \& D. Cameron (Eds.), Globalization and Language Teaching. London: Routledge. [electronic version] Retrieved on November 6, 2015 from http://language. la.psu.edu/ thorne/KramschThorne.html

Merriam, S. B. (2009). Qualitative Research: A Guide to Design and Implementation. San Francisco, California: Jossey-Bass.

Mertler, C. A. (2014). Action research: Improving Schools and Empowering Educators (3th ed.). Los Angeles, CA: Sage Publications.

Miles, M. B., \& Huberman, A. M. (1994). Qualitative data analysis: An expanded sourcebook. Thousand Oaks, CA: Sage.

Moeller, A. J., \& Nugent, K. (2014). Building intercultural competence in the language classroom. Faculty Publications: Department of Teaching, Learning and Teacher Education, 161, 1-19. Retrieved on September 14, 2015 http://digitalcommons.unl.edu/teachlearnfacpub/161.

O'Dowd, R. (2003). Understanding the "other side": Intercultural learning in a Spanish-Eng- lish-e-mail exchange. Language Learning \& Technology, 7(2), 118-144.

Patton, M. (2002). Qualitative Research and Evaluation Methods. Thousand Oaks, California: Sage.

Shetzer, H., \& Warschauer, M. (2000). An electronic literacy approach to network- based language teaching. In M. Warschauer \& R. Kern (Eds.), Network-based Language Teaching: Concepts and Practice (171-185). Cambridge: Cambridge University Press.

Shute, V. J. (2007). Focus on Formative Feedback, Research Report. ETS, Princeton, NJ. Retrieved on November 6, 2015 https://www.ets.org/Media/.../RR-07-11.pdf.

Stringer, E. (2007). Action Research. Thousand Oaks, CA: SAGE.

Waliński, J. (2012). Enhancing intercultural communicative competence in an online collaborative assessment environment: CEFcult project. Retrieved on November 6, 2015

http://anglistyka.uni.lodz.pl/userfiles/Walinski\%202012\%20Enhancing\%20intercultural\%20communicative\%20co mpetence.pdf

Williams, T. R. (2009). The Reflective Model of Intercultural Competency: A Multidimensional, Qualitative Approach to Study Abroad Assessment. Frontiers: The Interdisciplinary Journal of Study Abroad, 18, 289-306. Retrieved on September 14, 2015 http://www.frontiersjournal.com/documents/FrontiersXVIII-Fall09-TWilliams.pdf.

This work is licensed under a Creative Commons Attribution 3.0 License. 